\title{
ISOLATION OF CYTOMEGALOVIRUS IN AN INFANT WITH AN ANGIOSARCOMA
}

\author{
BY \\ HAROLD STERN, H. P. LAMBERT and W. G. SHAKESPEARE \\ From St. George's Hospital Medical School and St. George's Hospital, London
}

(RECEIVED FOR PUBLICATION JUNE 12, 1963)

\begin{abstract}
Cytomegalic inclusion-body disease occurs in its most characteristic form in the neonatal period as a fulminating disseminated infection in which jaundice, hepatosplenomegaly and haemorrhage associated with severe thrombocytopenia are the typical clinical features. In the older child the disease is very much rarer and the clinical picture is less well defined, but most patients present with predominantly respiratory and gastro-intestinal symptoms that are often superimposed on an underlying debilitating disease (Medearis, 1957). This report concerns a child aged 6 months who developed symptoms characteristic of the neonatal disease, and in whom cytomegalovirus infection was established by virus isolation, and an unusual type of abdominal tumour was discovered at autopsy. The respective roles of these two diseases in causing the clinical and pathological features of her illness raised a number of problems. This appears to be the first reported case in this country of the diagnosis of cytomegalovirus infection during life by virus isolation, and in which the possible source of the infection was traced by a family study.
\end{abstract}

\section{Case History}

Ann A. was born in England of Greek Cypriot parents. Her birth weight was $6 \mathrm{lb} .3 \mathrm{oz} .(2 \cdot 75 \mathrm{~kg}$.), delivery being normal and at term. Development was normal for the first six months apart from a mild bout of bronchitis at 3 months of age. Two doses of triple vaccine had been given at 4 and 5 months, but no smallpox vaccination. Her parents and three siblings aged $4 \frac{1}{2}, 3 \frac{1}{2}$ and 2 years were all healthy.

She was admitted to hospital at the age of 6 months, her illness having started three weeks before when she began to sleep poorly, was fretful and was unwilling to eat. She was constipated for two days and was given an aperient after which she had diarrhoea with loose green stools which continued until her admission. A week before admission there had been blood-staining of her stools on two occasions, and this had become more noticeable during the last two days. She had vomited about once a day for three weeks and much more often in the past two days when her abdomen became distended. Her parents were sure that she had lost weight during these last three weeks.

On admission the child was obviously unwell and had a rectal temperature of $100^{\circ} \mathrm{F}$. $\left(37 \cdot 8^{\circ} \mathrm{C}\right.$.). She weighed $14 \mathrm{lb} .6 \mathrm{oz} .(6 \cdot 53 \mathrm{~kg}$.). She was pale and had moderately large bruises on the forehead and both legs. The abdomen was distended and resonant. There were small capillary haemangiomata on her forehead and abdomen. No abdominal masses could be palpated and there was no jaundice. The other systems were normal. Her stools were loose, green and blood-stained.

Three days after admission she became slightly jaundiced and the liver was palpable with a uniform firm edge. During the next two days the jaundice deepened and the spleen was now palpable. Gaseous abdominal distension had become so considerable as to cause concern about the possibility of intestinal obstruction, although the bowels were moving, bowel sounds were normal and vomiting was no longer a feature. One week after admission she was deeply jaundiced, and the stools were now pale with occasional blood streaking, while the urine contained much bile. Over the following three weeks her general condition remained stable despite further deepening of the jaundice and the appearance of fresh bruising at various sites. About five to six weeks after admission to hospital her condition began to deteriorate slowly. She developed many petechiae on her back and later on her abdomen. Ascites appeared and rapidly increased in amount. Liver and spleen were moderately enlarged. She became very wasted and during the last week of her life began again to vomit, producing large volumes of foul-smelling, stale gastric residue. She died quietly 11 weeks after admission. At no time did she show any abnormal features in the cardiovascular or respiratory systems; there were no enlarged glands and there was no evidence of cerebral or meningeal disturbance.

Treatment. Three days after admission she was given a transfusion of $350 \mathrm{ml}$. fresh blood; two days later prednisone was started at a dose of $10 \mathrm{mg}$. q.i.d. and a further transfusion of $120 \mathrm{ml}$. platelet-rich plasma was administered. The prednisone was continued in dimin- 
ishing dosage during her stay in hospital, but neither the drug nor the transfusions appeared to have any effect on the platelet count or the bleeding tendency. Three weeks after admission she was given $250 \mathrm{mg}$. gamma globulin, because of contact with a case of measles in the ward. The ascites was tapped several times, but re-formed quickly.

\section{Laboratory Investigations}

Haemoglobin on admission was 7.0 g. $/ 100 \mathrm{ml}$. (48\%) and then rose after transfusion to $12 \cdot 3 \mathrm{~g} . / 100 \mathrm{ml}$. ( $84 \%$ ), but subsequently fell slowly to $8 \cdot 2 \mathrm{~g} . / 100 \mathrm{ml}$. (56\%). White cell counts and differentials were always normal. Reticulocytes on three occasions were between 2 and $2.6 \%$. The platelet count on admission was 20,000 per c.mm. and all subsequent counts were less than 30,000 except for one reading of 72,000 . Prothrombin time, three weeks after the onset of the jaundice, was 19 seconds compared with a control reading of 13 seconds. The blood group was $\mathrm{A}$ rhesus negative. Coombs' test and sickling test were both negative. Electrophoresis showed the presence of haemoglobin $A$ and no $A_{2}$. Foetal haemoglobin was $1 \cdot 5 \%$. Marrow aspiration showed normoblastic hyperplasia with a myeloid-erythroid ratio of $1: 2$. Red cell maturation was normal apart from the occurrence of occasional macronormoblasts. White cells were normal. Megakaryocytes were present in normal numbers but showed some abnormal features such as incomplete nuclear segmentation and failure to bud off platelets. There was no evidence of leukaemia or marrow failure.

The urine contained no reducing substances and no urobilinogen; Fouchet's test for bilirubin was positive. On the third day after admission serum bilirubin was $3.2 \mathrm{mg}$. $/ 100 \mathrm{ml}$. Liver function tests showed the following results; alkaline phosphatase 20 King-Armstrong units, thymol turbidity $5 \cdot 4$ units, thymol flocculation a trace, serum glutamic oxalacetic transaminase (S.G.O.T.) 60 units, serum glutamic pyruvic transaminase (S.G.P.T.) 36 units. Thereafter the serum bilirubin rose to $13.2 \mathrm{mg} . / 100 \mathrm{ml}$. $(9.8 \mathrm{mg}$. conjugated and $3.4 \mathrm{mg}$. free), and then fell to $9.0 \mathrm{mg}$. four weeks before death. The alkaline phosphatase fell to 15 units, thymol turbidity remained unchanged and the thymol flocculation test became positive. On further testing the S.G.O.T. was 35 units and the S.G.P.T. 68 units. Total plasma proteins on two occasions were 5.9 and $6.7 \mathrm{~g} . / 100 \mathrm{ml}$.; electrophoresis showed a slight reduction of albumin and slight increase of $\alpha_{1}, \alpha_{2}$, and $\gamma$ globulins. The ascitic fluid contained $2 \cdot 2 \mathrm{~g}$. protein $/ 100 \mathrm{ml}$. Serum cholesterol was $372 \mathrm{mg} . / 100 \mathrm{ml}$.

The urine showed no abnormality in the centrifuged deposit. Chromatography demonstrated a generalized aminoaciduria; there was no excess of phenylalanine. A gastrografin barium meal and follow-through showed no abnormality in stomach, duodenum or small intestine.

Stool cultures on four occasions grew no pathogenic bacteria, and a throat swab contained normal flora only. Toxoplasma complement-fixation and dye tests were negative at a serum dilution of 1 in 4 . The serum contained 0.05 to 0.1 units of diphtheria antitoxin and 1 to
2 units of tetanus antitoxin, as determined by the Wellcome Research Laboratories who stated that these were normal antibody responses to the two doses of triple vaccine that the patient had received.

\section{Virological Investigations}

Virus Isolation. Specimens were processed and cultured usually within two hours of collection. Throat swabs were extracted into $2 \mathrm{ml}$. of neutralized Hanks' solution containing penicillin, streptomycin and nystatin. Early morning urine specimens were neutralized to litmus immediately after collection and later centrifuged at 3,000 r.p.m. for 15 minutes; the deposit was resuspended in $2 \mathrm{ml}$. of the supernatant and both supernatant and the resuspended deposit used for isolation attempts. Three tubes each of HeLa cells, primary human amnion, primary monkey kidney and diploid human embryonic lung fibroblasts were inoculated with $0.1 \mathrm{ml}$. amounts of prepared specimens. The latter cells were prepared according to the method of Hayflick and Moorhead (1961) and were in their 12th passage when the first specimens were examined; the cells were maintained on medium 199 containing $2 \%$ newborn calf serum. Inoculated tubes were refed after 24 hours and then at three- to five-day intervals during the period of observation. All cultures were incubated at $36-37^{\circ} \mathrm{C}$.

Five pairs of throat swabs and urines were examined at intervals during the infant's illness and virus was isolated from all 10 specimens. Isolations were made only in the fibroblast cultures. Cytopathic effects were noted within five to 12 days with both throat swab and urine specimens. and in the case of the latter there was little difference between the supernatant and deposit fractions in either time of appearance or number of lesions. The lesions were strictly focal in nature and consisted of groups of swollen rounded or oval, slightly refractile cells. The foci increased in number only very slowly, and each focus increased slowly in size by peripheral extension while the central cells eventually degenerated with accumulation of granular debris. Even after four to six weeks, however, only about half the fibroblast monolayer was involved by the cytopathic process. Staining with haemalum and eosin showed the presence within infected cells of large, irregular, eosinophilic, intranuclear inclusion bodies. Multinucleated cells were absent. Passage of the virus was possible only by using inocula consisting of ground infected tissue, producing cytopathic effects identical to those in the primary cultures. Cell-free supernatant was non-infective until after the second passage when it produced only scanty lesions 12 to 15 days later than did ground tissue. Subculture of the virus to HeLa, amnion or monkey kidney could not be achieved. These various characteristics are typical of cytomegaloviruses. Quantitative studies were carried out on a single urine specimen taken three weeks before death; the supernatant titred $10^{4}$ TCID (tissue culture infective dose) $/ \mathrm{ml}$.

Three specimens of ascitic fluid and two of faeces were also cultured for virus, but no virus was isolated.

At autopsy, specimens of liver, kidney, salivary gland, brain, lung, blood and tumour were obtained for virus 
isolation. Ground extracts, $20 \%$, of the various tissues in Hanks' were prepared and inoculated into fibroblast cultures. Cytomegalovirus was isolated from kidney and salivary gland, but not from liver, lung, brain, blood or tumour, although inoculated cultures were observed over a period of six weeks.

Serology. The patient's serum was examined on three occasions for complement-fixing antibody, using as antigen ground cells plus supernatant from fibroblast cultures infected with the Kerr strain of cytomegalovirus (Weller, Macauley, Craig and Wirth, 1957); the complement-fixation antibody titre in all three sera was 16 . Neutralizing antibody was estimated, using the patient's own virus in its fourth passage; the titre was 64, against a recorded virus challenge dose of $50 \mathrm{TCID}_{50}$.

Family Study. Throat swabs and urines were obtained from the parents of the patient and from three siblings. Cytomegalovirus was isolated from both specimens of all three children, but not from the parents. Serum complement-fixation antibody titres were 32, 64 and 64 for the three siblings aged 2, 3 and 4 years, and 16 and 128 for the father and mother respectively.

\section{Post-mortem Findings}

The autopsy was reported on by Dr. P. Pullar of the Pathology Department, St. George's Hospital Medical School.

Alimentary System. The tongue, fauces and oesophagus were normal. The peritoneal cavity contained $450 \mathrm{ml}$. of deeply bile-stained fluid. The retroperitoneal tissues of the upper and middle thirds of the abdomen were infiltrated by an irregular tumour mass that extended also into the root of the mesentery of the large and small bowel. The tumour measured approximately $15 \mathrm{~cm}$. across, and consisted of firm fleshy tissue in which there were widespread small areas of recent haemorrhage. It surrounded the tissues behind the stomach and the first part of the duodenum, but did not appear to cause serious obstruction to the outflow of bile. Small areas of old and recent haemorrhage were present throughout the greater part of the small intestine. The liver weighed $235 \mathrm{~g}$., was of average size and was deeply bile stained. Although its normal architecture was preserved it was of extremely firm consistency, but with no gross evidence of increase in fibrous tissue. There was nothing of note in the gall-bladder or bileducts, and the region of the pancreas was almost completely replaced by the tumour mass.

All other systems of the body were normal.

Histology. The tumour was an angiosarcoma (Fig. 1). The liver showed marked bile retention with periportal fibrosis; extensive areas of necrosis were present but were not associated with any reactive process. Apart from some congestion all other tissues had normal histology.

In no tissue were inclusion-bearing cells found. Numerous blocks of both kidney and liver were repeatedly examined for such cells, but without success.

\section{Discussion}

Infection with the cytomegaloviruses is common. It has long been recognized that 5 to $15 \%$ of infants who die from unrelated causes have in their salivary glands the characteristic cytomegalic cells with their large intranuclear inclusion bodies (Smith and Vellios, 1950; Baar, 1955; Symmers, 1960). More recently serological studies have shown the presence of antibodies in a high proportion of adults (Rowe, Hartley, Waterman, Turner and Huebner, 1956; Weller et al., 1957); in London the proportion is $40 \%$ (H. Stern and S. D. Elek, 1961, unpublished observations). Disease on the other hand is rare. The clinical picture varies with the age of the patient. It is most striking in the neonatal period. The baby is often premature and the principal symptoms, which are present at birth or appear shortly afterwards, are jaundice, hepatosplenomegaly, anaemia and thrombocytopenic purpura. The course is commonly fulminating and fatal, and recovery is associated with severe mental deficiency, microcephaly, motor disability and blindness (Weller and Hanshaw, 1962). Recovery, however, is possible, either complete or with minimal mental and motor disability (Birdsong, Smith, Mitchell and Corey, 1956; McElfresh and Arey, 1957; Weller, Hanshaw and Scott, 1960; Elliott and Elliott, 1962; Gear, le Roux, Kessel and Sichel, 1962). Cases that come to autopsy illustrate the disseminated nature of the disease with cytomegalic cells in many tissues throughout the body.

The complete neonatal picture is extremely rare in older infants and children. Some of the features may occur but the course is usually dominated by symptoms of respiratory and gastro-intestinal tract involvement (Medearis, 1957). Because of the indeterminate nature of the illness the diagnosis is almost invariably made only at autopsy, the cytomegalic cells being either localized to the respiratory and/or intestinal tracts or more widely distributed. Many of these postnatal cases are associated with some other debilitating disease such as pertussis or fibrocystic disease of the pancreas, which may have been largely responsible for the dissemination of an otherwise minor and localized infection.

Our patient showed jaundice, hepatosplenomegaly, anaemia and thrombocytopenic purpura, the picture typical of the neonatal form. Although the complete syndrome does not appear to have been reported in the postnatal period, a diagnosis of cytomegalic inclusion disease was considered and apparently confirmed by isolation of the virus from the throat and urine. Despite the known association of cytomegalic virus infection in the postnatal period with other diseases, no other diagnosis could be 


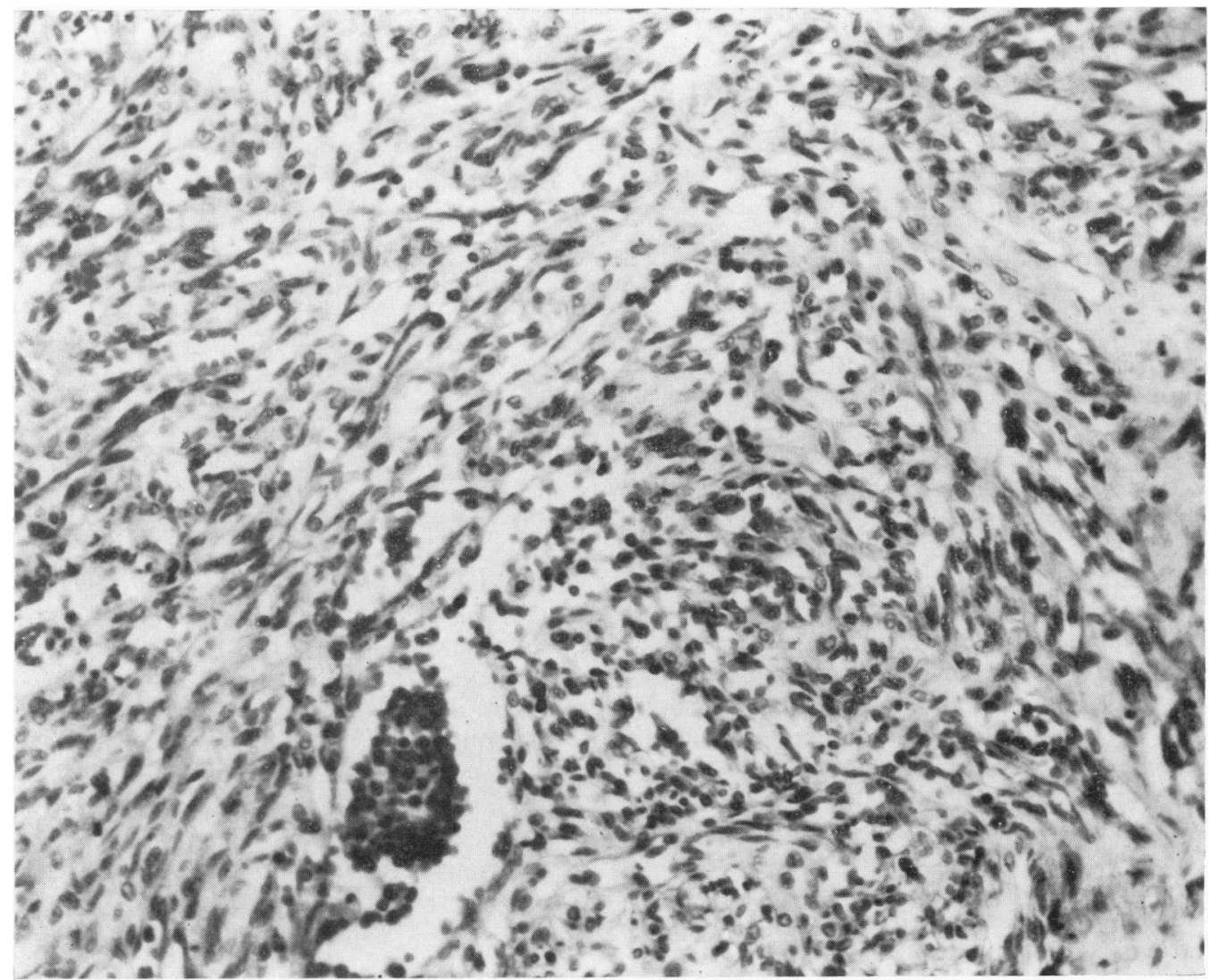

FIGURE.-Photomicrograph of a section of the angiosarcoma. (H. and E. $\times 300$.)

established during life, and the sarcoma was identified only at autopsy.

What were the respective roles of virus and tumour in the genesis of her disease? The jaundice was biochemically and pathologically obstructive in type, and this is the usual finding in cytomegalic inclusion disease. Intrahepatic cholestasis and biliary cirrhosis may occur (Smith and Vellios, 1950; Nelson and Wyatt, 1959; Crome, 1961), and the large direct-reacting component of the serum bilirubin has also been noted (Weller and Hanshaw, 1962). On the other hand, although the common bile-duct was patent at autopsy and bile could be shown to flow into the duodenum, the duct was surrounded by tumour and the histological findings favoured extrahepatic obstruction. Moreover, the virus was not isolated from liver tissue. On balance, it seems likely that the jaundice and enlarged liver and spleen may have been caused entirely by the retroperitoneal sarcoma. The other main feature, thrombocytopenic purpura, is also difficult to evaluate since, although well known in cytomegalic inclusion disease, it also occurs very rarely in association with large haemangiomata (Kontras, Green, King and Duran, 1963), the thromcytopenia being apparently caused by sequestration of platelets in the vascular channels of the tumour. The extremely vascular nature of our patient's sarcoma makes it necessary to take this possibility into account. It is impossible to be certain about the relative importance of virus and tumour in causing this child's illness, but it is a curious paradox that an unusual clinical syndrome known to result from infection by the virus isolated from this patient could indeed have been caused in its entirety by the abdominal tumour, leaving the virus infection as an incidental and clinically insignificant finding. Apart from the tumour itself, no special factor that might have increased the child's susceptibility to infection could be identified. The plasma protein pattern was normal and the serum responses to diphtheria and tetanus immunization were within the normal range. The association of 
cytomegalovirus infection and malignancy has been previously reported by Hanshaw and Weller (1961) who detected excretion of cytomegalovirus in four out of 50 infants and children with acute leukaemia and other forms of disseminated neoplasia. One of the four had respiratory symptoms and typical cytomegalic cells were found at autopsy in the lungs. Two of the three other children also died but neither showed any histological evidence of the virus infection.

The absence of cytomegalic inclusions in a careful search of the organs at autopsy is an important finding, since it shows clearly that identification of these cells is a relatively crude method of detecting cytomegalovirus infection. In our patient virus was isolated repeatedly from the urine, yet a careful search of the kidneys failed to reveal cytomegalic inclusion cells. Likewise, no cytomegalic cells could be seen in the salivary glands, although virus was present in the mouth. Weller and Hanshaw (1962) isolated the virus from four liver biopsy specimens taken from cases of neonatal hepatitis, but found characteristic cells in two only, and in one of these only with difficulty. During life diagnosis can be made by finding characteristic 'owl's eye' cells in the urinary sediment, but this method is quite clearly much less sensitive than virus isolation (Rowe, Hartley, Cramblett and Mastrota, 1958; Weller and Hanshaw, 1962), and we too were unable to find these cells in the urine although virus was repeatedly isolated from it. Until isolation of human cytomegalovirus was first achieved (Smith, 1956; Rowe et al., 1956; Weller et al., 1957) diagnosis was entirely histological and based on finding the characteristic large cell with its large intranuclear inclusion. It is now clear that this criterion will not serve to identify all changes caused by this virus; the clinical spectrum of cytomegalic inclusion disease may thus be widened now that virus isolation can be more easily achieved.

The source of our patient's infection was undoubtedly the other siblings in the household, all three of whom, although symptom free, were excreting virus in the throat and urine. Infection was probably originally acquired from other schoolchildren. About $10 \%$ of children aged 5 to 10 years in London have antibodies (H. Stern and S. D. Elek, 1961, unpublished observations). In Boston, $0.7 \%$ of normal children excrete cytomegalovirus in their urines and among children in institutions and close household contacts this figure is increased to 20 to $24 \%$ (Hanshaw and Simon, 1962). The latter workers found that abnormal liver function tests were common in the children who were excreting virus, but results of tests (thymol turbidity, thymol flocculation and alkaline phosphatase) carried out on our patient's three siblings were within normal limits.

\section{Summary}

A 6-months-old infant developed jaundice, hepatosplenomegaly and thrombocytopenic purpura. Isolation of cytomegalovirus from both throat and urine appeared to confirm the diagnosis of cytomegalic inclusion disease, but at autopsy a large angiosarcoma was found infiltrating the retroperitoneal region and no cytomegalic cells could be demonstrated on histological examination of the patient's tissues. The tumour was probably responsible both for the jaundice and the thrombocytopenic purpura.

The cytomegalovirus infection may thus have had no clinical significance, but absence of cytomegalic inclusion cells in the organs at autopsy does not rule out a possible pathogenic role for the virus, since evidence is presented that it can cause infection of an organ without producing the characteristic cell.

The source of the virus infection was traced by a family study.

We are indebted to Dr. J. C. McEntee for permission to publish this case, and also to Dr. D. P. Winstanley for the results of the bone marrow examination.

\section{REFERENCES}

Baar, H. S. (1955). Interstitial plasmacellular pneumonia due to pneumocystis carinii. J. clin. Path., 8, 19.

Birdsong, M., Smith, D. E., Mitchell, F. N. and Corey, J. H., Jr. (1956). Generalized cytomegalic inclusion disease in newborn infants. J. Amer. med. Ass., 162, 1305.

Crome, L. (1961). Cytomegalic inclusion-body disease. Wld Neurol., 2, 447.

Elliott, G. B. and Elliott, K. A. (1962). Observations on cerebral cytomegalic inclusion disease of the foetus and newborn. Arch. cytomegalic inclusion
Dis. Childh., 37,34 .

Gear, J., le Roux, A. F., Kessel, I. and Sichel, R. (1962). Generalized cytomegalic inclusion disease. A review and a report of the isolation of virus from cases occurring in Johannesburg. S. Afr. med. J., 36, 8.

Hanshaw, J. B. and Simon, G. (1962). Cytomegaloviruses in the urine of children with hepatomegaly and abnormal liver function tests. Amer. J. Dis. Child., 104, 555.

and Weller, T. H. (1961). Urinary excretion of cytomegaloviruses by children with generalized neoplastic disease. $J$. viruses by chil
Pediat., 58, 305.

Hayflick, L. and Moorhead, P. S. (1961). The serial cultivation of human diploid cell strains. Exp. Cell Res., 25, 585.

Kontras, S. B., Green, O. C., King, L. and Duran, R. J. (1963). Giant hemangioma with thrombocytopenia. Amer. J. Dis. Child., 105, 188.

McElfresh, A. E. and Arey, J. B. (1957). Generalized cytomegalic inclusion disease. $J$. Pediat, $51,146$.

Medearis, D. N. (1957). Cytomegalic inclusion disease. An analysis of the clinical features based on the literature and six additional cases. Pediatrics, 19, 467.

Nelson, J. S. and Wyatt, J. P. (1959). Salivary gland virus disease. Medicine (Baltimore), 38, 223.

Rowe, W. P., Hartley, J. W., Cramblett, H. G. and Mastrota, F. M. (1958). Detection of human salivary gland virus in the mouth and urine of children. Amer. J. Hyg., 67, 57.

- Waterman, S., Turner, H. C. and Huebner, R. J. (1956). Cytopathogenic agent resembling human salivary gland virus recovered from tissue cultures of human adenoids. Proc. Soc. recovered from tissue cult
exp. Biol. $(N . Y), 92,$.418 .

Smith, M. G. (1956). Propagation in tissue cultures of cytopathogenic virus from human salivary gland virus (SGV) disease. ibid., 92, 424. 
- and Vellios, F. (1950). Inclusion disease or generalized salivary gland virus infection. Arch. Path., 50, 862.

Symmers, W. St. C. (1960) Generalized cytomegalic inclusion-body disease associated with pneumocystis pneumonia in adults. J. clin. Path., 13, 1 .

Weller, T. H. and Hanshaw, J. B. (1962). Virologic and clinical observations on cytomegalic inclusion disease. New Engl. J. Med., 266, 1233. and Scott, D. E. (1960). Virologic and clinical investigaChild., 100,469 .

- Macauley, J. C., Craig, J. M. and Wirth, P. (1957). Isolation of intranuclear inclusion producing agents from infants with of intranuclear inclusion producing agents from infants with
illnesses resembling cytomegalic inclusion disease. Proc. Soc. illnesses resembling cyto
exp. Biol. (N.Y.), 94, 4. 